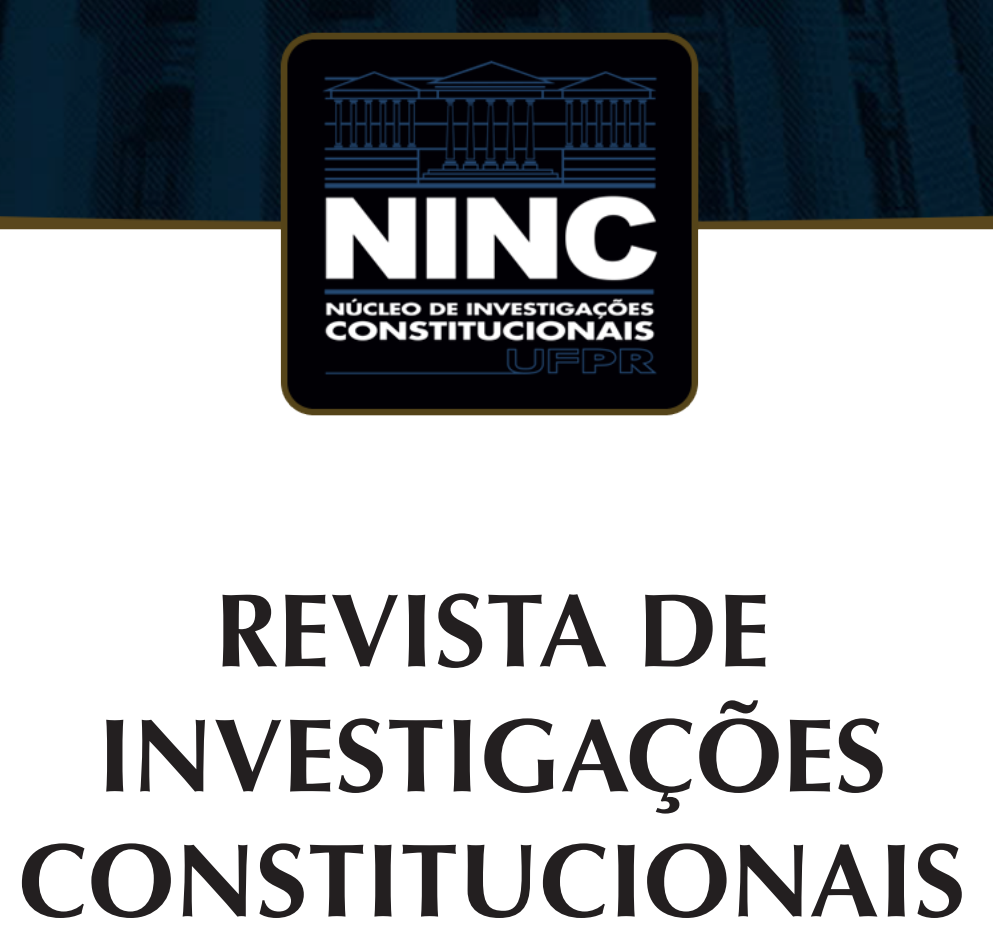

JOURNAL OF CONSTITUTIONAL RESEARCH

vol. 5 | n. 1 | janeiro/abril 2018 | ISSN 2359-5639 | Periodicidade quadrimestral Curitiba | Núcleo de Investigações Constitucionais da UFPR | www.ninc.com.br 


\title{
Influência das teorias dos diálogos institucionais e da última palavra provisória no pensamento constitucional brasileiro contemporâneo
}

\section{Influence of the theories of institutional dialogues and the last provisional word in contemporary Brazilian constitutional thinking}

\author{
ANTONIO EZEQUIEL INÁCIO BARBOSA* \\ Universidade de Fortaleza (Brasil) \\ antonioezequiel@gmail.com
}

MARTONIO MONT'ALVERNE BARRETO LIMA**

Universidade de Fortaleza (Brasil) barreto@unifor.br

Recebido/Received: 16.10.2017 / October 16 th, 2017 Aprovado/Approved: 31.12.2017 / December 31st, 2017

Resumo

O presente artigo trata de pesquisa sobre a influência das teorias dos diálogos institucionais e da última palavra provisória no pensamento constitucional brasileiro contemporâneo. Investiga-se se essas teorias têm aptidão para servir de fundamento teórico à possibilidade jurídica de superação, pelo Poder Legislativo, das decisões proferidas pelo Supremo Tribunal Federal no exercício do controle jurisdicional de constitucionalidade. A conclusão é positiva e assenta-se na premissa de que a superação legislativa é decorrência lógica do princípio democrático consagrado pela Constituição de 1988. Ademais, são examinados os modos pelos quais o fenômeno

\section{Abstract}

This article deals with a research on the influence of institutional dialogue theories and the last provisional word on contemporary Brazilian constitutional thought. It is investigated if these theories have aptitude to serve as theoretical foundation to the legal possibility of overcoming, by the Legislative Power, the decisions pronounced by the Federal Supreme Court in the exercise of jurisdictional control of constitutionality. The conclusion is positive and is based on the premise that legislative overcoming is a logical consequence of the democratic principle enshrined in the 1988 Constitution. In addition, it examines the ways in which the phenomenon of legislative overcoming can occur

\footnotetext{
Como citar esse artigo/How to cite this article: BARBOSA, Antonio Ezequiel Inácio; LIMA, Martonio Mont'alverne Barreto. “Influência das teorias dos diálogos institucionais e da última palavra provisória no pensamento constitucional brasileiro contemporâneo. Revista de Investigações Constitucionais, Curitiba, vol. 5, n. 1, p. 109-128, jan./abr. 2018. DOI: 10.5380/rinc.v5i1.55825.

* Mestrando em Direito Constitucional pelo Programa de Pós-Graduação em Direito Constitucional da Universidade de Fortaleza (Fortaleza, CE, Brasil). Defensor Público Federal. E-mail: antonioezequiel@gmail.com.

** Professor Titular da Universidade de Fortaleza (Fortaleza, CE, Brasil). Doutor em Direito pela Joahann Wolfgang Goethe-Universität/Frankfurt am Main (Alemanha).Procurador do Município de Fortaleza. E-mail: barreto@unifor.br.
} 
da superação legislativa pode ocorrer - emenda constitucional ou lei ordinária ou complementar -, com as características, exigências e implicações de cada um.

Palavras-chave: teoria dos diálogos institucionais; teoria da última palavra provisória; controle de constitucionalidade; superação legislativa.
- constitutional amendment or ordinary or complementary law -, with the characteristics, requirements and implications of each.

Keywords: theory of institutional dialogues; theory of the last provisional word; control of constitutionality; overcoming legislation.

\section{SUMÁRIO}

1. Introdução; 2. A possibilidade de superação legislativa das decisões proferidas pelo STF no exercício da jurisdição constitucional; 3. Contornos gerais das teorias do diálogo institucional e da última palavra provisória e sua aplicabilidade na realidade constitucional brasileira; 4. A superação legislativa pela via da emenda constitucional; 5. A superação legislativa pela via da lei ordinária ou complementa; 6 . Conclusão; 7. Referências.

[...] porque nenhum se contenta com crescer dentro da espécie: a andorinha quer subir a águia; a rémora quer crescer a baleia; a formiga quer inchar a elefante; [...] Desenganemo-nos que o crescer fora da própria espécie, não é aumento, é monstruosidade; ao menos benção não é. $1^{* * *}$

(António Vieira)

\section{INTRODUÇÃO}

Os Poderes da União devem se relacionar entre si de modo independente e harmônico, por força de exigência expressa da Constituição da República de 1988 (CR/1988). Não obstante, o próprio poder constituinte originário delineou uma estrutura bastante complexa de repartição funcional entre o Legislativo, o Executivo e o Judiciário. Demais, já se deve ter por claro que o conflito integra o conceito de democracia e, por esta razão, a separação de poderes possui em sua natureza explicativa a evidente percepção de que o conflito entre os Poderes também estará presente. Decorre daí a natureza do liberal princípio da separação de poderes a reconhecer, antes de tudo, o conflito entre os poderes.

Desse modo, na realidade cotidiana concreta, nem sempre é muito nítida a delimitação do campo de atuação legítima das instituições, o que pode dar ensejo a embates envolvendo acusações recíprocas de invasão das esferas de competência próprias de cada Poder. Exemplo notável disso é o tipo de relação, não raro conflituoso, que se estabelece entre, de um lado, o Legislativo e o Executivo, como produtores de leis e atos normativos e, de outro lado, o Judiciário, responsável pelo controle de constitucionalidade dessa produção.

1 *** VIEIRA, António. Sermão da Terceira Dominga do Advento. V. I. Obras Completas do Padre António Vieira - Sermões. Porto: Lello \& Irmão Editores, 1993. p. 265-266. 
Nos últimos anos intensificam-se os debates sobre os limites da atuação do Supremo Tribunal Federal (STF) no exercício da jurisdição constitucional. Tornaram-se comuns as discussões sobre o chamado ativismo judicial, que se caracteriza pela ocupação, por parte do Poder Judiciário, de espaços institucionais próprios do Poder Legislativo, em especial, o da deliberação a respeito das opções políticas que devem balizar a vida em sociedade e o da fixação das regras do jogo democrático.

Por outro lado, não se verifica no Brasil, ao menos não com a mesma abundância e profundidade, a existência de estudos e discussões sobre o fenômeno da reação legislativa em face das decisões proferidas pelo STF em sede controle de constitucionalidade. Daí a relevância de se pesquisar essa nuance das relações desenvolvidas entre o Poder Judiciário e o Poder Legislativo. E é justamente esse o tema versado no presente artigo, a partir da perspectiva de elementos do Estado Democrático de Direito delineado na CR/1988 e da investigação da influência das teorias dos diálogos institucionais e da última palavra provisória no pensamento constitucional brasileiro contemporâneo.

Nessa esteira, o trabalho em tela foi desenvolvido mediante o instrumento metodológico da pesquisa bibliográfica, com consultas a livros, artigos científicos e decisões proferidas pelo STF. No primeiro tópico, foi investigada a possibilidade jurídica de superação legislativa das decisões proferidas pelo STF no exercício da jurisdição constitucional. No segundo, foram examinados os contornos gerais e a aplicabilidade das teorias do diálogo institucional e da última palavra provisória, invocadas como fundamentos dessa prática, na realidade constitucional brasileira. Nos tópicos terceiro e quarto, foram pesquisados, os modos de possíveis de reação legislativa ao controle jurisdicional de constitucionalidade, quais sejam, a emenda constitucional e a lei ordinária ou complementar, com as características, exigências e implicações próprias de cada alternativa.

\section{A POSSIBILIDADE DE SUPERAÇÃO LEGISLATIVA DAS DECISÕES PROFERIDAS PELO STF NO EXERCÍCIO DA JURISDIÇÃO CONSTI- TUCIONAL}

O constitucionalismo moderno afirmou-se historicamente depois do fim da Segunda Guerra Mundial, em razão da insuficiência da legalidade e do positivismo jurídico, de índole liberal, como meios de contenção do poder e de proteção do ser humano.

Diante da constatação de que regimes políticos autoritários foram capazes de promover atrocidades dentro de um quadro de legalidade formal, "a ideia de um ordenamento jurídico indiferente a valores éticos e da lei como uma estrutura meramente 
formal, uma embalagem para qualquer produto, já não tinha mais aceitação no pensamento esclarecido" 2 .

Nesse contexto, consolidou-se a suplantação do Estado legislativo de direito pelo Estado constitucional de direito, produto "de las Constituciones rígidas y del control de constitucionalidad de las leyes ordinarias"3. Daí a formulação de concepções que afirmam existir relação necessária entre a "centralidade da Constituição e a supremacia judicial, como tal entendida a primazia de um tribunal constitucional ou suprema corte na interpretação final e vinculante das normas constitucionais"4.

Essa compreensão, porém, está longe de ser pacificamente aceita. Parece inegável que o constitucionalismo se consolidou como uma compreensão de mundo vitoriosa e hegemônica. Contudo, a pretendida associação necessária entre constitucionalismo e supremacia judicial, marcada pela prerrogativa da última palavra sobre a interpretação das normas constitucionais, tem sido crescentemente questionada.

Em primeiro plano, aponta-se a denominada dificuldade contramajoritária, decorrente da existência de um déficit democrático de cortes formadas por juízes vitalícios, que não foram escolhidos pelo voto popular, nem se submetem regularmente ao escrutínio das urnas, para invalidar atos que são fruto da deliberação política dos representantes eleitos pelo povo.

Nesse sentido, Martonio Lima assinala que o controle da constitucionalidade das leis e atos normativos, "realizado por quem não possui legitimidade popular alguma não satisfaz os requisitos de uma teoria da democracia, na medida em que a composição das cortes não é produto da apreciação direta do povo, mas sim um resultado da escolha dos representantes" 5 .

Em linhas semelhantes, Ran Hirschl afirma que a transferência de prerrogativas tradicionais dos Poderes Legislativo e Executivo ao Judiciário pode servir como instrumento de proteção das preferências políticas de elites interessadas na preservação de sua hegemonia, sem a necessidade de enfrentar uma luta constante nas arenas próprias à tomada de decisões dessa natureza6.

De modo mais incisivo, Mark Tushnet defende uma concepção de constitucionalismo popular, assentada na ideia de que todos devem participar da criação do direito

\footnotetext{
2 BARROSO, Luís Roberto. O novo direito constitucional brasileiro: contribuições para a construção teórica e prática da jurisdição constitucional do no Brasil. Belo Horizonte: Fórum, 2013. p. 120.

3 FERRAJOLI, Luigi. Pasado y futuro del estado de derecho. Revista internacional de filosofía política. Madrid, n. 17, p. 31-46, 2001. p. 31 .

4 BARROSO, Luís Roberto. 0 controle de constitucionalidade no direito brasileiro: exposição sistemática da doutrina e análise crítica da jurisprudência. 6. ed. São Paulo: Saraiva, 2012. p. 365.

5 LIMA, Martonio Mont'Alverne Barreto. Jurisdição Constitucional: um problema da Teoria da Democracia Política. In: SOUZA NETO, Cláudio Pereira; BERCOVICI, Gilberto; MORAES FILHO, José Filomeno; __ . (Org.). Teoria da Constituição: Estudos sobre o Lugar da Política no Direito Constitucional. Rio de Janeiro: Lumen Juris, 2003. p. 199-261.

6 HIRSCHL, Ran. Towards juristocracy: the origins and consequences of the new constitutionalism. Cambridge, MA: Harvard University Press, 2009. p. 214.
} 
constitucional, por meio de ações na política; em suas palavras "popular constitutional law seeks to distribute constitutional responsibility throughout the population"7. A consequência prática dessa linha de pensamento é a supressão da competência da Suprema Corte para ditar a última palavra em sede de interpretação constitucional.

De qualquer modo, em que pesem a consistência e a relevância das críticas ao modelo do controle jurisdicional da constitucionalidade das leis, o fato é que esse sistema está assentado no texto constitucional brasileiro. Trata-se de uma opção política feita pelo poder constituinte originário, que se vincula ao postulado da separação dos Poderes e que, portanto, tem o seu núcleo essencial protegido por cláusula pétrea (artigo 60, § 4. ${ }^{\circ}$, inciso III8).

Isso não significa, porém, que não se possa discutir o modo de exercício da jurisdição constitucional, com vistas a preservar o caráter democrático que deve permear todas as manifestações do poder estatal em nosso país. No contexto dessa discussão, é pertinente a indagação sobre a possibilidade jurídica de o Poder Legislativo superar o entendimento firmado pelo STF no desempenho da jurisdição constitucional.

A resposta afigura-se afirmativa. Realmente, ao teor do disposto no artigo 102, § $2 .^{\circ}$, da CR/1988, as decisões definitivas de mérito proferidas pelo STF, nas ações diretas de inconstitucionalidade e nas ações declaratórias de constitucionalidade, terão efeito vinculante apenas com relação aos demais órgãos do Poder Judiciário e à administração pública direta e indireta nas esferas federal, estadual e municipal. Vê-se, então, que essa vinculação não alcança o Poder Legislativo.

Evidencia-se, portanto, a partir do próprio texto constitucional, que é juridicamente possível que o Parlamento reaja às decisões proferidas pelo STF no exercício da jurisdição constitucional. Essa possibilidade, ademais, decorre da própria lógica do Estado Democrático de Direito preconizado pela Constituição, cujo artigo 1. \% parágrafo único, estabelece que todo poder emana do povo, que o exerce por meio de representantes eleitos ou diretamente.

A propósito, conquanto digam respeito a uma outra realidade normativa constitucional, parecem bastante atuais as seguintes palavras de Francisco Campos, registradas em uma entrevista que ele concedera à imprensa em novembro de 1937:

Ora, a interpretação não dispõe de processos objetivos e infalíveis e, por isto mesmo, está sujeita à influência do coeficiente pessoal do juiz. Não há, portanto, nenhuma razão para aceitar como decisiva ou definitiva, no plano em que se acham em jogo os maiores interesses da nação, uma interpretação que não dá nenhuma garantia objetiva do seu acerto. Aos juízes não será, em conseqüência, permitido, a pretexto de interpretação

\footnotetext{
7 TUSHNET, Mark. Taking the Constitution away from the courts. Princeton: Princeton University Press, 1999. p. 174.

8 Não será objeto de deliberação a proposta de emenda tendente a abolir a separação dos poderes.
} 
constitucional, decretar como única legítima a sua filosofia social ou a sua concepção do mundo, desde que essa filosofia ou concepção obstrua os desígnios econômicos, políticos ou sociais do governo, em benefício da nação. ${ }^{9}$

Ora, se o Poder Legislativo estivesse perenemente vinculado ao entendimento firmado pelo STF nas ações de controle de constitucionalidade, o poder pertencente à Suprema Corte seria impermeável a qualquer influxo democrático e, portanto, marcado por contornos autocráticos. E o princípio democrático é incompatível com qualquer manifestação de poder dessa natureza. Nesse sentido, Giovanni Sartori assinala:

Que a tese seja, então, que democracia é não-autocracia, o contrário exato e, na verdade, a exata contradição de autocracia. Isso significa que democracia denota um sistema político caracterizado pela recusa do poder personalizado, de um poder sobre os cidadãos que pertence a alguém. O poder não é "propriedade" de ninguém. Mais especificamente, democracia representa um sistema vinculado ao princípio de que ninguém pode assumir em seu próprio nome um poder irrevogável. Exatamente porque o princípio autocrático é repudiado, o axioma democrático é que o poder do homem sobre o homem só pode ser concedido por outros - e sempre numa base revogável (de outra forma, as pessoas que concedem o poder renunciariam, ao mesmo tempo, a seu poder). Portanto, os dirigentes devem resultar de uma designação livre e irrestrita daqueles que devem ser dirigidos. [...] Qualquer outra coisa que democracia possa ser, ou deva ser, se não for isso - o exato inverso de autocracia - ela não existe. ${ }^{10}$

Não se pode olvidar que o Poder Legislativo é "a instância política por excelência, como tal, a mais representativa da soberania popular e do pluralismo político, social e ideológico existente na sociedade, pois nele estão representadas todas as suas tendências"11. Por outro norte, "o perfil aristocrático do judiciário, assim como sua organização interna de caráter verticalizado e autocrático, inviabiliza na prática o exercício do pluralismo político e ideológico nas atividades judicantes"12, de modo que "o controle

\footnotetext{
9 CAMPOS, Francisco. O Estado nacional. Brasília: Senado Federal, 2001. Disponível em <http://www2.senado.leg.br/bdsf/ item/id/1056>. Acesso em 15 out. 2017. p. 59.

10 SARTORI, Giovanni. A teoria da democracia revistada. v. I. Tradução de Dinah de Abreu Azevedo. São Paulo: Ática, 1994. p. 277.

11 ROCHA, José de Albuquerque. Estudos sobre o poder judiciário. São Paulo: Malheiros, 1995. p. 53.

12 ALBuQueRQuE, Newton de Menezes. Crise do judiciário e sua democratização. Revista Pensar, Fortaleza, v. 4, n. 4, p. 151170, jan. 1996. p. 162-163.
} 
jurisdicional-constitucional de normas, conforme sua estrutura, representa resistência à formação democrática de vontade"13.

A judicialização da política demonstra de maneira mais clara como a apropriação, pelas cortes constitucionais, da esfera do político em desfavor do Poder Legislativo tem se efetivado, e quais seus resultados na qualidade da democracia. Atualmente, o funcionamento dos tribunais constitucionais levou à opinião pública em geral e a intelectualidade a se conformarem com esta realidade. A dúvida a ser agora enfrentada é a seguinte: foi sempre assim? O que adverte a história sobre o assunto?

A supremacia do Poder Legislativo não é novidade. Diante da conotação teórica, esta supremacia tem sido aceita mesmo antes de sua materialização, notadamente durante a Revolução Francesa. Na sua Metafísica dos Costumes, Immanuel Kant não deixa dúvidas quanto à preponderância do Poder Legislativo, sobre o Judiciário. Pertence a Kant a afirmação de que "Todo Estado contém em si três poderes, isto é, a vontade geral se une em três pessoas políticas (trias politica): o poder soberano (a soberania), que reside no poder legislativo; o poder executivo, que reside em quem governa (segundo a lei) e o poder judiciário, (que possui a tarefa de dar a cada um o que é seu, na conformidade da lei), na pessoa do juiz (...)"14.

Interpretação segura a respeito do postulado de Kant que afirma a supremacia do poder legislativo é presente na obra de Norberto Bobbio, quando este, recorrendo à Metafísica dos Costumes, entende que "Apesar da afirmação da subordinação de um poder ao outro, o fundamento da separação dos três poderes é ainda a supremacia do poder legislativo sobre os outros dois poderes: o poder legislativo deve ser superior porque somente ele representa a vontade coletiva"15. Antecedendo a Immanuel Kant, Jean-Jacques Rousseau defendeu também a supremacia do Legislativo: "O poder legislativo é o coração do Estado, o poder executivo é o cérebro, que dá o movimento a todas as partes. $O$ cérebro pode cair em paralisia e o indivíduo prosseguir vivendo. Um homem fica imbecil e vive, mas assim que o coração cessar suas funções, o animal está morto. Não é pela lei que o Estado subsiste, mas pelo poder legislativo"16.

Lançada está a base teórica da crítica à formulação da jurisdição constitucional enquanto pretensa defensora da supremacia constitucional. É legítimo que se ponha em dúvida, portanto, o papel da jurisdição constitucional como protetora da

\footnotetext{
13 MAUS, Ingeborg. Direito, democracia e racionalidade procedimental. Belo Horizonte: Del Rey, 2009. p. 283.

14 KANT, Immanuel. Metaphysik der Sitten. Band 7. Darmstadt: Wissenschaftliche Buchgesellschaft, Sonderausgabe, 1983. p. 431-432. No original: „Ein jeder Staat enthält drei Gewalten in sich, d.i. den allgemein vereinigten Willen in dreifacher Person (trias politica): die Herrschende Gewalt (Souveränität), in der des Gesetzgebers, die vollziehende Gewalt, in der des Regiers (zu Folge dem Gesetz), und die rechtsprechende Gewalt (als Zuerkennung des Seinen eines jeden nach dem Gesetz), in der Person des Richters (potestas legislatoria, rectoria ej iudiciaria), gleich den drei Sätzen in einem praktischen Vernunftsschluß: dem Oberstaz, der das Gesetz jenes Willens, dem Untersatz, der das Gebot des Verfahrens nach dem Gesetza, d.i. das Prinzip der Subsumtion unter deselben, und den Schlußstz, der den Rechtspruch (die Sentenz) enthält, was im vorkommenden Falle Rechtens ist."
}

15 BOBBIO, Norberto. Direito e Estado no Pensamento de Emmanuel Kant. São Paulo: Editora Mandarim, 2000. p. 227.

16 ROUSSEAU, Jean-Jacques. Do Contrato Social ou Princípios do Direito Político. São Paulo: Hemus, 1981. p. 96. 
supremacia constitucional, quando ela própria é suprema para o Estado e perante os demais poderes.

A crítica ainda se estende. Como conciliar a jurisdição constitucional com o princípio de soberania popular se cotidianamente seu exercício não somente desfaz o que foi realizado pela vontade coletiva representada no poder legislativo, como ainda desloca a discussão do político para seu reduzido recinto, onde a heterogeneidade das tensões sociais jamais estará presente? Não há de se olvidar que a capacidade dialógica dos tribunais para com as forças políticas e sociais presentes em qualquer sociedade é infinitamente menor do que aquela dos espaços do Poder Legislativo. Discursivamente, somente possuem acesso ao intricado processo de decisão judicial constitucional especialistas e versados no manejo da dogmática jurídica, episódio que não se constata no âmbito do Poder Legislativo. Tampouco este saber refinadamente formulado tem se demonstrado imprescindível, uma vez que a natureza da discussão política pode perfeitamente tanto se organizar em ambientes leigos, como pode a população, pela via da participação inclusiva, discernir sobre o que é melhor para si na produção de soluções racionais.

A versão kantiana da situação dos três poderes fornece o ponto de partida para a afirmação de que a existência da jurisdição constitucional é incompatível com o princípio de soberania popular. Na medida em que o poder que representa a vontade coletiva se vê limitado pelas decisões de um tribunal constitucional, se constata a inversão da superioridade da vontade coletiva. O Poder Legislativo comprova a invalidação de suas decisões por uma corte que não enfrentou a vontade popular. Ainda que tais cortes sejam formadas por membros indicados pelo Poder Legislativo, o vício da legitimidade não está sanado: estes membros irão controlar a constituição, e no desempenho desta tarefa a possibilidade de ultrapassagem dos limites traçados pelo constituinte é inevitável.

É procedente a preocupação de que os poderes constituídos poderão sempre ultrapassar o delineamento constitucional. Este quadro de possibilidade tem se mostrado muito mais corriqueiro do que se imaginava após as demandas rápidas de tomada de decisão impostas pela globalização econômica. Por outro lado, forçosa será a dúvida quanto a quem compete mensurar esta ultrapassagem, tornando-a, se for o caso, inválida, como fazem as cortes constitucionais. Se o Poder Legislativo ou o Executivo exorbitam o limite definido pelo constituinte, a alguém deverá competir a tarefa de resolver o problema, de forma a adequar tanto a solução quanto o seu processo ao que é determinado pelo mesmo texto constitucional.

O que a razão lluminista recomenda, segundo nosso entendimento, é que o processo de invalidação desta ultrapassagem seja ele próprio resolvido por quem possui legitimidade da vontade coletiva para tal inerente à sua natureza institucional. Como a legitimidade coletiva não se institui, mas sim pertence à essência de uma idéia (e 
da idéia do Poder Legislativo), a ultrapassagem somente poderá ser corrigida por este poder ou por algum organismo interior a ele, uma vez que a exterioridade ao Poder Legislativo da jurisdição constitucional é que compromete o seu caráter democrático, por ser o titular exterior portador da vontade coletiva de que nos fala Immanuel Kant.

A retirada da prerrogativa do Poder Legislativo do controle direto sobre a constitucionalidade se reveste desta maneira numa alternativa conservadora, já que a faculdade de invalidação dos atos do Legislativo reside no círculo Judiciário, tradicional aliado do Executivo absolutista, modernamente domesticado. Como bem sintetiza Tocqueville, "No ponto em que se movimentam, príncipe e juristas, se origina um despotismo que mal deixa o ar para o homem respirar; quem somente refletir sobre o príncipe - e não sobre os juristas - conhecerá apenas umlado da tirania. Para conhecer o todo é necessário ter os dois - príncipe e juristas - diante dos olhos"17. Por fim, é interessante mostrar a leitura de Kant que Ingeborg Maus realiza a respeito da "inversão" (Umkehrung), representada pela preponderância da jurisdição constitucional: "A nova predominância da justiça constitucional sobre o parlamento representa para a relação do exercício institucionalizado e não institucionalizado da soberania popular uma inversão da função da constituição em si"18.

Existe, ainda, mais um ponto a fortalecer o caráter conservador da jurisdição constitucional, qual seja o de seu papel de poder acima das disputas. Este ponto merece especial consideração, pelo fato de que a experiência político-institucional brasileira conviveu durante sessenta e sete anos com um poder acima dos demais, no caso o poder moderador da Constituição de 1824. A conformação de um poder moderador, pretensamente neutro não é novidade e até os dias de hoje se revela com capacidade argumentativa (e mobilizatória) para, por exemplo, justificar um eventual retorno da monarquia. O seu viés teológico é patente: um poder neutro somente é possível se infalível, já que deverá ser exercido por alguém educado - pelo e com o peso da tradição - para lidar com tais situações desde a mais tenra idade. Discursivamente, o poder Moderador era "chave de todo Império", sendo seu exercício da estrita competência do imperador. O problema da manutenção do equilíbrio entre os poderes do Estado avançou na sua vertente liberal a ponto de não mais se satisfazer somente com a tradicional divisão de poderes, mas sim de estabelecer também um mecanismo de controle dos poderes, na medida em que se sofisticavam as exigências políticas e sociais reformuladas

\footnotetext{
17 TOCQUEVILLE, Alexis de. Die gesellschaftiche un politische Zustände Frankreiches vor und nach 1798. In: TOCQUEVILLE, Alexis de. Das Zeitalter der Gleichheit - Auswahl aus Werken und Briefen. Zweite neubearbeitete und erweitere Auflage. Hrsg. u. übersetzt v. Siegfried Landshut. Köln und Opladen: Westdeutscher Verl., 1967. p. 117-140. p. 133. No original: "An dem Schnittpunkt, an dem sie sich begegnen, entsteht ein Despotismus, der der Menschheit kaum die Luft zum atmen läßt; wer nur an den Fürsten denkt, nicht an den Juristen, kennt nur eine Seit der Tyrannei. Um das Ganze zu erfassen, muß man aber beide zugleich im Auge haben."

18 MAUS, Ingeborg. Zur Aufklärung der Demokratietheorie - Rechts- und demokratietheoretische Überlegungen im Anschluß an Kant. Frankfurt/M.: Surhkamp, 1992. p. 132. No original: "Für das Verhältnis von institutionalisierter un nichtinstitutionalisierter Ausübung der Volkssouveränität aber bringt die neue Dominaz der Verfassungsjuztiz gegenüber dem Parlament eine Umkehrung der Funktions der Verfassung selbst mit sich."
} 
pela Revolução Francesa. Como para os fathers da Constituição dos Estados Unidos da América o povo era mantido fora da possibilidade decisória de conformação dos poderes do Estado, o papel de controlador da constitucionalidade por meio de uma corte igualmente imune ao controle popular e do Legislativo preencheria o requisito liberal de estabelecimento de uma democracia limitada e, paradoxalmente, legitimada por sua própria sociedade, como têm provado seus mais de duzentos anos de vida. Seja na forma de poder moderador ou de corte suprema o fato é que a necessidade de um controle superior existe e até os dias atuais este argumento não parecer ter perdido em força.

A jurisdição constitucional funcionando como a instância moderadora dos eventuais abusos do Poder Legislativo e de sua maioria parlamentar assegura a estabilidade desejada pelos liberais. Aqui outro aspecto merece reflexão. Sistemas liberais não raro abrem espaço político para representação política externa ao círculo liberal: a Inglaterra sempre conviveu com governos trabalhistas e atualmente os governos que se definem social-democratas na Europa e no Brasil praticam abertamente políticas liberais, satisfazendo as exigências do "mercado". Potencialmente, a jurisdição constitucional, principalmente com a dilatação cada vez maior dos instrumentos de controle concentrado da constitucionalidade no Brasil, tem funcionado como compensação em favor do liberalismo contra a presença nos parlamentos de grupos heterogêneos e de orientação anti-liberal, bem como dos resultados de suas deliberações. Neste sentido, a jurisdição constitucional reencarna duas exigências que somente com o auxílio da teoria política se pode melhor compreende-los: a) suas decisões correspondem - e nesta qualidade são aceitas pela sociedade política - à moderação do conflito entre os poderes; e b) seu funcionamento se traduz na perene desconfiança cultural que a mesma sociedade política possui dos parlamentos e de sua capacidade de elaborar leis e espécies normativas constitucionais.

Assim, a conclusão deve ser positiva também como consequência necessária do regime político democrático. Impedir que o Parlamento possa agir para superar o entendimento assentado pelo STF equivaleria a admitir que o poder deliberativo último não emana do povo, mas, da Suprema Corte. Significaria, ademais, preconizar que o poder de estabelecer as opções políticas da nação, bem como as regras do jogo democrático, não é exercido por meio de representantes eleitos, mas, sim, por integrantes do órgão de cúpula do Poder Judiciário. 


\section{CONTORNOS GERAIS DAS TEORIAS DO DIÁLOGO INSTITUCIO- NAL E DA ÚLTIMA PALAVRA PROVISÓRIA E SUA APLICABILIDA- DE NA REALIDADE CONSTITUCIONAL BRASILEIRA}

Da admissão de uma Constituição rígida, como centro do ordenamento jurídico, decorre o postulado da supremacia constitucional. Em face desse princípio, todas as situações jurídicas devem ser conformadas com os princípios e preceitos constitucionais, de modo que nenhuma lei ou ato normativo - na verdade, nenhum ato jurídico - pode subsistir validamente se estiver em desconformidade com a Constituição'19.

A partir da centralidade constitucional, foi engendrado o paradigma da supremacia judicial, uma vez que a verificação de conformidade das leis com a Constituição é uma tarefa confiada ao Poder Judiciário, notadamente ao seu órgão de cúpula (tribunais constitucionais ou cortes supremas).

Contudo, se admitida essa supremacia, ela não deve ser confundida com soberania judicial. Efetivamente, da disposição constitucional segundo a qual os Poderes da União são independentes e harmônicos entre si, é forçoso concluir que a relação existente entre eles é de coordenação e não de subordinação. Daí porque não se afigura correto supor que um Poder possa impor o seu entendimento aos outros de modo definitivo, sob nenhum aspecto, nem mesmo a pretexto do desempenho de suas funções típicas.

Isso significa que a supremacia judicial somente deve ser compreendida em um sentido fraco, como a impossibilidade jurídica de uma decisão jurisdicional proferida em sede de controle de constitucionalidade vir a ser invalidada pelo Poder Legislativo. Significa, ademais, que a decisão jurisdicional, uma vez transitada em julgado, será imutável no âmbito da relação jurídica processual em que foi proferida, sem possibilidade de sua alteração pelo Parlamento.

Todavia, o Poder Legislativo não estará eternamente atado ao entendimento firmado no exercício da jurisdição constitucional. Como já mencionado no tópico anterior, a Constituição não impõe ao Parlamento nenhum tipo de vinculação nesse sentido (artigo 102, § 2..$^{\circ}$.

Aos parlamentares sempre será possível a aprovação de emendas constitucionais, ou mesmo a edição de leis ordinárias ou complementares, sobre temas já decididos pelo STF, desde que agregando novos fundamentos com vistas a superar o entendimento firmado pela Corte Suprema. Esse modo de proceder não deve ser encarado como uma afronta à autoridade do órgão de cúpula do Poder Judiciário. Diferentemente disso, deve ser visto como saudável manifestação dialogal da democracia representativa.

19 BARROSO, Luís Roberto. O controle de constitucionalidade no direito brasileiro: exposição sistemática da doutrina e análise crítica da jurisprudência. 6. ed. São Paulo: Saraiva, 2012. p. 23. 
E a nova produção legislativa - emenda constitucional ou lei ordinária ou complementar -, surgida como reação a uma decisão exarada no exercício da jurisdição constitucional, sempre poderá ser novamente submetida ao crivo do STF, guardião da Constituição.

É nesse contexto que se insere a teoria dos diálogos institucionais20, sob uma perspectiva que contempla a atuação política de múltiplos sujeitos, de modo a transpor compreensão de que os tribunais constitucionais ou cortes supremas seriam dotados de legitimidade superior e final para interpretar a Constituição. Conforme assinalam SILVA et al, trata-se de uma nova ótica,

[...] que incorpora a presença e a atuação política de outros atores - opõe-se aos anteriores marcos teóricos do judicial review, que tradicionalmente consideram apenas a alternativa dicotômica de um dos agentes, associada a uma manifestação final apta a interromper o processo dialético de construção do verdadeiro sentido constitucional. ${ }^{21}$

Daí a se falar não mais na existência de um Poder com o monopólio da última palavra, mas, sim na construção de uma prática dialógica que possibilite a convivência do constitucionalismo com a democracia. Poderes independentes e harmônicos, justamente porque dotados desses qualificativos, devem ser capazes de aprimoramento contínuo e dialético a respeito de questões relevantes para o país. O Parlamento pode e deve participar da tarefa de interpretação da Constituição, como interlocutor privilegiado, dada a sua configuração de instância representativa da vontade popular para as deliberações políticas.

Advertem Daniel Sarmento e Cláudio Pereira de Souza Neto:

[...] não é salutar atribuir a um órgão qualquer a prerrogativa de dar a última palavra sobre o sentido da Constituição. Definitivamente, a Constituição não é o que o Supremo diz que ela é. Em matéria de interpretação constitucional, a Corte, composta por intérpretes humanos e falíveis, pode errar, como também podem fazê-lo os poderes Legislativo e Executivo. É preferível adotar- se um modelo que não atribua a nenhuma instituição — nem do Judiciário, nem do Legislativo — o "direito de errar por último", abrindo-se a permanente possibilidade de correções recíprocas no campo da hermenêutica

\footnotetext{
20 O cenário internacional registra diversas experiências de aplicação de teorias dialógicas de interpretação constitucional. Na obra Diálogos constitucionais e ativismo, Cecília de Almeida Silva et al (2010, p. 58-90) examinam as práticas adotadas no Canadá, em Israel, na Nova Zelândia, no Reino Unido e na Austrália. Nessa tarefa, apontam como marco inicial a previsão constante da Carta de Direitos Canadense de 1982, conhecida como "cláusula não obstante" (notwithstanding clause), por meio da qual o Legislativo pode aplicar um diploma normativo ainda que ele seja considerado inconstitucional pelo Judiciário.

21 SILVA, Cecília de Almeida et al. Diálogos institucionais e ativismo. Curitiba: Juruá, 2010. p. 101.
} 
constitucional, com base na ideia de diálogo, em lugar da visão mais tradicional, que concede a última palavra nessa área ao STF.

\section{$[\ldots]$}

As decisões do STF em matéria constitucional são insuscetíveis de invalidação pelas instâncias políticas. Isso, porém, não impede que seja editada uma nova lei, com conteúdo similar àquela que foi declarada inconstitucional. Essa posição pode ser derivada do próprio texto constitucional, que não estendeu ao Poder Legislativo os efeitos vinculantes das decisões proferidas pelo STF no controle de constitucionalidade (art. 102, § 20,e art. 103-A, da Constituição). Se o fato ocorrer, é muito provável que a nova lei seja também declarada inconstitucional. Mas o resultado pode ser diferente. O STF pode e deve refletir sobre os argumentos adicionais fornecidos pelo Parlamento ou debatidos pela opinião pública para dar suporte ao novo ato normativo, e não ignorá-los, tomando a nova medida legislativa como afronta à sua autoridade. Nesse ínterim, além da possibilidade de alteração de posicionamento de alguns ministros, pode haver também a mudança na composição da Corte, com reflexos no resultado do julgamento. 22

Nessa ambiência, a postura dialogal, longe de representar o desprestígio ao âmbito de atribuições próprias de cada instituição surge como componente necessário e lubrificante do postulado da separação dos Poderes. Implica a admissão de que a Corte Suprema e o Congresso Nacional são atores legitimados ao exercício da interpretação constitucional, de modo a afastar toda pretensão de sobreposição hierárquica por parte de qualquer um deles.

Desse modo, a decisão proferida pelo STF em sede de controle de constitucionalidade será apenas provisoriamente a última palavra sobre o tema que constitui o seu objeto. Será o derradeiro pronunciamento até que sobrevenha outro do Poder Legislativo, que então assumirá temporariamente a função de última palavra, enquanto não seja realizado novo julgamento pela Corte Constitucional. E assim sucessivamente, em um espiral dialético-argumentativo, em que cada nova manifestação sobre o assunto eleva a discussão para um outro patamar.

22 SARMENTO, Daniel; SOUZA NETO, Cláudio Pereira de. Direito constitucional: teoria, história e métodos de trabalho. Belo Horizonte: Fórum, 2012. p. 402-405. 


\section{A SUPERAÇÃO LEGISLATIVA PELA VIA DA EMENDA CONSTITU- CIONAL}

Quando o Poder Legislativo reage ao controle jurisdicional de constitucionalidade por meio da aprovação de uma emenda constitucional, verifica-se a alteração do próprio fundamento de validade invocado pela Suprema Corte para proferir a sua decisão. Nessa hipótese, o parâmetro utilizado para verificar a compatibilidade das normas infraconstitucionais com a Lei Maior deixa de existir, tal como antes fora concebido, para dar lugar a um paradigma normativo constitucional diferente.

Um exemplo de reação legislativa bem-sucedida, efetivada por meio de emenda constitucional, diz respeito ao custeio do serviço de iluminação pública. No dia 10 de março de 1999, o Plenário do STF, ao julgar os recursos extraordinários n. 231.764 e 233.332, decidiu que esse serviço não pode ser remunerado por meio da espécie tributária taxa. Esse entendimento foi aplicado reiterada e pacificamente pela Corte em um grande número de julgamentos, o que levou à edição da Súmula n. $670^{23}$ em idêntico sentido.

Diante desse quadro e atento à necessidade da administração pública de auferir recursos para a finalidade em questão, o Congresso Nacional aprovou a Emenda Constitucional n. 39/2002, que inseriu o artigo 149-A na Constituição, para autorizar os Municípios e o Distrito Federal a instituir contribuição para o custeio do serviço de iluminação pública.

Uma vez promulgada a nova emenda constitucional, a superação legislativa consolidou-se, mediante tão somente a alteração da espécie tributária possível de ser exigida para o custeio do mencionado serviço público. Nesse caso específico, a mudança afigura-se mais terminológica (de taxa para contribuição) do que conceitual.

De todo modo, não é dado ao Poder Judiciário controlar o mérito da modificação operada no texto constitucional como resultante da deliberação política realizada pelo Parlamento. Dessarte, nesse tipo de situação, o controle de constitucionalidade possível de ser realizado pelo STF sobre a emenda constitucional será restrito ao exame da observância das disposições contidas no artigo 60 da CR/199824, que estabelece

\footnotetext{
23 Posteriormente, na data de 11 de março de 2015, o Plenário do STF converteu a Súmula 670 na Súmula Vinculante n. 41.

24 Art. 60. A Constituição poderá ser emendada mediante proposta:

I- de um terço, no mínimo, dos membros da Câmara dos Deputados ou do Senado Federal;

II - do Presidente da República;

III - de mais da metade das Assembléias Legislativas das unidades da Federação, manifestando-se, cada uma delas, pela maioria relativa de seus membros.

$\S 1^{\circ} \mathrm{A}$ Constituição não poderá ser emendada na vigência de intervenção federal, de estado de defesa ou de estado de sítio.

$\S 2{ }^{\circ} \mathrm{A}$ proposta será discutida e votada em cada Casa do Congresso Nacional, em dois turnos, considerando-se aprovada se obtiver, em ambos, três quintos dos votos dos respectivos membros.

$\S 3^{\circ} \mathrm{A}$ emenda à Constituição será promulgada pelas Mesas da Câmara dos Deputados e do Senado Federal, com o respectivo
} 
limitações formais (incisos I, II, III e $\S \S 2 .^{\circ}, 2 .^{\circ}, 3^{\circ}$ e $\left.5 .^{\circ}\right)$, circunstanciais $\left(\S 1 .^{\circ}\right)$ e materiais (§ 4..$^{\circ}$ ) ao poder constituinte reformador.

\section{A SUPERAÇÃO LEGISLATIVA PELA VIA DA LEI ORDINÁRIA OU COMPLEMENTAR}

De outro giro, é significativamente mais exigente a utilização da via da lei ordinária ou complementar para a superação da decisão do STF que julga inconstitucional alguma norma legal ou que lhe impõe determinada interpretação. É que, nesse caso, incumbirá ao Poder Legislativo o ônus argumentativo de comprovar a legitimidade de sua atuação para ultrapassar o entendimento firmado pela Suprema Corte no exercício da jurisdição constitucional.

Natural que seja desse modo. Assim como é dever do Poder Judiciário, principalmente do ponto de vista jurídico, motivar suas decisões, incumbe ao Poder Legislativo, especialmente do ponto de vista político, a explicitação argumentativa dos fundamentos invocados para a reinserção normativa que desafia o precedente da Suprema Corte. Com efeito, "uma norma vale moralmente quando ela, perante cada um que aceita uma fundamentação racional, pode ser justificada"25.

A argumentação é um procedimento instrumental destinado à resolução de problemas ${ }^{26}$. Argumentar, jurídica ou politicamente, significa oferecer razões que justifiquem uma determinada decisão. A justificação dever ser suficiente e adequada, guiando-se "por uma racionalidade exterminadora do arbítrio casuístico, não a racionalidade cartesiana da lógica da lei, mas sim a racionalidade do discurso argumentativo pós-positivista justificado"27. Deveras, embora os componentes retóricos tenham importância decisiva na argumentação política, eles não bastam para sustentar uma argumentação dirigida a justificar a superação dialógica de uma decisão jurisdicional.

número de ordem.

$\S 4^{\circ}$ Não será objeto de deliberação a proposta de emenda tendente a abolir:

I - a forma federativa de Estado;

II - o voto direto, secreto, universal e periódico;

III - a separação dos Poderes;

IV - os direitos e garantias individuais.

25 ALEXY, Robert. Direitos Fundamentais no Estado Constitucional Democrático. Para a relação entre direitos do homem, direitos fundamentais, democracia e jurisdição constitucional. Tradução de Luís Afonso Heck. Revista de Direito Administrativo, Rio de Janeiro, n. 217, p. 55-66, jul./set. 1999. p. 60.

26 ATIENZA, Manuel. Curso de Argumentación Jurídica. Madrid:Trotta, 2013. p. 643.

27 ROESLER, Claudia Rosane; PEIXOTO, Fabiano Hartmann. Judicialização do direito: análise de decisão de controle concreto de constitucionalidade abstrativizada como base para a possibilidade de avaliação de sua racionalidade. Revista Pensar, Fortaleza, v. 14, n. 2, p. 240-254, jan./jul. 2009. p. 253. 
Tem valor nesse contexto uma importante regra da teoria da argumentação jurídica: "quem quiser se afastar de um precedente, assume a carga da argumentação" 28. Na ausência de argumentação idônea a suplantar os fundamentos invocados na decisão proferida pelo STF, o diploma legislativo editado com o objetivo de superar o entendimento firmado pela Corte Suprema não subsistirá a um novo exame de sua constitucionalidade.

Exemplo dessa natureza foi verificado com relação aos artigos $1 .^{\circ}$ e $2 .^{\circ}$ da Lei n. 12.875/2013, que introduziram, respectivamente, modificações na Lei n. 9.096/1995 (Lei Orgânica dos Partidos Políticos) e na Lei n. 9.504/1997 (Lei das Eleições). Em suma, as alterações levadas a efeito, mediante proposta legislativa que tramitou em regime de urgência, tinham o propósito de excluir os partidos novos, criados depois da realização da eleição para a Câmara dos Deputados, do acesso ao tempo destinado à propaganda eleitoral no rádio e na televisão (o chamado direito de antena) e à distribuição proporcional do fundo partidário.

Buscou-se com isso a superação do entendimento firmado pelo Plenário do STF quando do julgamento conjunto das ações diretas de inconstitucionalidade (ADI's) n. 4.430 e 4.795, no seguinte sentido:

[...] Extrai-se do princípio da liberdade de criação e transformação de partidos políticos contido no caput do art. 17 da Constituição da República o fundamento constitucional para reputar como legítimo o entendimento de que, na hipótese de criação de um novo partido, a novel legenda, para fins de acesso proporcional ao rádio e à televisão, leva consigo a representatividade dos deputados federais que, quando de sua criação, para ela migrarem diretamente dos partidos pelos quais foram eleitos. Não há razão para se conferir às hipóteses de criação de nova legenda tratamento diverso daquele conferido aos casos de fusão e incorporação de partidos (art. 47, §4, Lei das Eleições), já que todas essas hipóteses detêm o mesmo patamar constitucional (art. 17, caput, CF/88), cabendo à lei, e também ao seu intérprete, preservar o sistema. Se se entende que a criação de partido político autoriza a migração dos parlamentares para a novel legenda, sem que se possa falar em infidelidade partidária ou em perda do mandato parlamentar, essa mudança resulta, de igual forma, na alteração da representação política da legenda originária. Note-se que a Lei das Eleições, ao adotar o marco da última eleição para deputados federais para fins de verificação da representação do partido (art. 47, § 3०, da Lei 9.504/97), não considerou a hipótese de criação de nova legenda. Nesse caso, o que deve prevalecer não é o desempenho do partido nas eleições (critério inaplicável aos novos partidos), mas, sim, a representatividade política conferida aos parlamentares que

28 ALEXY, Robert. Teoria da argumentação jurídica. Tradução de Zilda Hutchinson Schild Silva. 2. ed. São Paulo: Malheiros, 2005. p. 267. 
deixaram seus partidos de origem para se filiarem ao novo partido político, recém criado. Essa interpretação prestigia, por um lado, a liberdade constitucional de criação de partidos políticos (art. 17, caput, CF/88) e, por outro, a representatividade do partido que já nasce com representantes parlamentares, tudo em consonância com o sistema de representação proporcional brasileiro. 29

Ocorre que essa reação legislativa foi impugnada por meio da ADI 5.105, ao argumento central de desrespeito ao que fora decidido pelo STF sobre o tema. Ao fim, o pedido veiculado nessa nova ação de controle concentrado de constitucionalidade foi julgado procedente para declarar a inconstitucionalidade dos artigos $10^{\circ}$ e $2 .^{\circ} \mathrm{da}$ Lei n. 12.875/2013. O fundamento decisivo para esse resultado foi a ausência de argumentação suficiente para a superação do entendimento que houvera sido firmado pela Corte Suprema, como se verifica dos fragmentos da ementa respectiva, a seguir reproduzidos:

[...] 7. O Congresso Nacional, no caso sub examine, ao editar a Lei no 12.875/2013, não apresentou, em suas justificações, qualquer argumentação idônea a superar os fundamentos assentados pelo Supremo Tribunal Federal, no julgamento das ADIs no 4430 e no 4795, rel. Min. Dias Toffoli, em que restou consignado que o art. 17 da Constituição de 1988 - que consagra o direito político fundamental da liberdade de criação de partidos - tutela, de igual modo, as agremiações que tenham representação no Congresso Nacional, sendo irrelevante perquirir se esta representatividade resulta, ou não, da criação de nova legenda no curso da legislatura.

9. No caso sub examine, a justificação do projeto de lei limitou-se a afirmar, em termos genéricos, que a regulamentação da matéria, excluindo dos partidos criados o direito de antena e o fundo partidário, fortaleceria as agremiações partidárias, sem enfrentar os densos fundamentos aduzidos pelo voto do relator e corroborado pelo Plenário. [...] $]^{30}$

\footnotetext{
29 BRASIL. Supremo Tribunal Federal. Julgamento conjunto das ações diretas de inconstitucionalidade n. 4.430 e 4.795. Brasília, DF, 29 de junho de 2013. Disponível em <http://www.stf.jus.br/portal/processo/verProcessoAndamento.asp?incidente=3903848>. Acesso em: 15 out. 2017.

30 BRASIL. Supremo Tribunal Federal. Ação direta de inconstitucionalidade n. 5.105. Brasília, DF, 1. de outubro de 2015. Disponível em <http://www.stf.jus.br/portal/processo/verProcessoAndamento.asp?incidente=4552286>. Acesso em: 15 out. 2017.
} 
Vê-se, pois, que para estabelecer um diálogo institucional autêntico é indispensável que o Parlamento deduza razões diferentes daquelas já apreciadas pelo STF, de modo idôneo e suficiente a afastar os fundamentos utilizados no julgamento que se pretende superar. Para transcender à última palavra provisória vigente, é necessária a demonstração de que foram substancialmente alteradas as razões de fato e de direito que serviram de esteio para a decisão da Suprema Corte. Afinal, de acordo com a ordem natural das coisas, a mera reedição de uma lei já retirada do ordenamento jurídico por eiva de inconstitucionalidade estará fadada a receber idêntica censura por parte da jurisdição constitucional.

\section{CONCLUSÃO}

As teorias dos diálogos institucionais e da última palavra provisória influenciam o pensamento constitucional brasileiro contemporâneo na medida em que explicam e fundamentam a possibilidade de superação legislativa das decisões proferidas pelo STF no exercício da jurisdição constitucional. À luz dessas teorias, a reação do Poder Legislativo ao controle jurisdicional da constitucionalidade das leis é uma decorrência lógica da consagração pela CR/1988 do princípio democrático (artigo 1.) e dos postulados da harmonia e independências dos Poderes (artigo 1. ${ }^{\circ}$, parágrafo único), bem como da ausência de vinculação do Parlamento aos pronunciamentos da Suprema Corte (artigo $102, \S 2{ }^{\circ}$, da Lei Maior).

De acordo com as diretrizes desse arcabouço teórico, nas hipóteses em que a superação legislativa for concretizada por meio de emenda constitucional, somente será cabível o controle jurisdicional de constitucionalidade destinado a verificar o respeito às limitações formais, circunstanciais e materiais previstas no artigo 60 da Constituição.

As referidas teorias, ademais, reforçam a compreensão no sentido de que não há espaço para poderes absolutos nem para decisões jurídico-políticas irrefutáveis em um Estado Democrático de Direito. Não subsiste ao princípio democrático nenhuma manifestação autocrática de poder, invocada como prerrogativa exclusiva e inderrogável de uma pessoa ou instituição. Uma vez que o poder emana do povo, os seus representantes eleitos podem e devem estar atentos às decisões de controle de constitucionalidade proferidas sobre o produto de suas deliberações políticas e jurídicas. Afigura-se legítimo, pois, que os cidadãos exijam, tanto do Parlamento quanto da Suprema Corte, uma postura republicana de respeito mútuo e cooperação recíproca, sem que uma instância se arrogue como proprietária da verdadeira e última interpretação do sentido e do alcance das normas constitucionais. 


\section{REFERÊNCIAS}

ALBUQUERQUE, Newton de Menezes. Crise do judiciário e sua democratização. Revista Pensar, Fortaleza, v. 4, n. 4, p. 151-170, jan. 1996.

ALEXY, Robert. Teoria da argumentação jurídica. Tradução de Zilda Hutchinson Schild Silva. 2. ed. São Paulo: Malheiros, 2005.

ALEXY, Robert. Direitos Fundamentais no Estado Constitucional Democrático. Para a relação entre direitos do homem, direitos fundamentais, democracia e jurisdição constitucional. Tradução de Luís Afonso Heck. Revista de Direito Administrativo, Rio de Janeiro, n. 217, p. 55-66, jul./set. 1999.

ATIENZA, Manuel. Curso de Argumentación Jurídica. Madrid:Trotta, 2013.

BARROSO, Luís Roberto. O novo direito constitucional brasileiro: contribuições para a construção teórica e prática da jurisdição constitucional do no Brasil. Belo Horizonte: Fórum, 2013.

BARROSO, Luís Roberto. $\mathbf{O}$ controle de constitucionalidade no direito brasileiro: exposição sistemática da doutrina e análise crítica da jurisprudência. 6. ed. São Paulo: Saraiva, 2012.

BOBBIO, Norberto. Direito e Estado no Pensamento de Emmanuel Kant. São Paulo: Editora Mandarim, 2000.

BRASIL. Supremo Tribunal Federal. Ação direta de inconstitucionalidade n. 5.105. Brasília, DF, 1. ${ }^{\circ}$ de outubro de 2015. Disponível em <http://www.stf.jus.br/portal/processo/verProcessoAndamento.asp?incidente=4552286>. Acesso em: 15 out. 2017.

BRASIL. Supremo Tribunal Federal. Julgamento conjunto das ações diretas de inconstitucionalidade n. 4.430 e 4.795. Brasília, DF, 29 de junho de 2013. Disponível em <http://www.stf.jus. br/portal/processo/verProcessoAndamento.asp?incidente=3903848>. Acesso em: 15 out. 2017.

CAMPOS, Francisco. O Estado nacional. Brasília: Senado Federal, 2001. Disponível em <http:// www2.senado.leg.br/bdsf/item/id/1056>. Acesso em 15 out. 2017.

FERRAJOLI, Luigi. Pasado y futuro del estado de derecho. Revista internacional de filosofía política. Madrid, n. 17, p. 31-46, 2001.

HIRSCHL, Ran. Towards juristocracy: the origins and consequences of the new constitutionalism. Cambridge, MA: Harvard University Press, 2009.

KANT, Immanuel. Metaphysik der Sitten. Band 7. Darmstadt: Wissenschaftliche Buchgesellschaft, Sonderausgabe, 1983.

LIMA, Martonio Mont'Alverne Barreto. Jurisdição Constitucional: um problema da Teoria da Democracia Política. In: SOUZA NETO, Cláudio Pereira; BERCOVICI, Gilberto; MORAES FILHO, José Filomeno; . (Org.). Teoria da Constituição: Estudos sobre o Lugar da Política no Direito Constitucional. Rio de Janeiro: Lumen Juris, 2003, p. 199-261. 
MAUS, Ingeborg. Direito, democracia e racionalidade procedimental. Belo Horizonte: Del Rey, 2009.

MAUS, Ingeborg. Zur Aufklärung der Demokratietheorie - Rechts- und demokratietheoretische Überlegungen im Anschluß an Kant. Frankfurt/M.: Surhkamp, 1992.

ROCHA, José de Albuquerque. Estudos sobre o poder judiciário. São Paulo: Malheiros, 1995.

ROESLER, Claudia Rosane; PEIXOTO, Fabiano Hartmann. Judicialização do direito: análise de decisão de controle concreto de constitucionalidade abstrativizada como base para a possibilidade de avaliação de sua racionalidade. Revista Pensar, Fortaleza, v. 14, n. 2, p. 240-254, jan./jul. 2009.

ROUSSEAU, Jean-Jacques. Do Contrato Social ou Princípios do Direito Político. São Paulo: Hemus, 1981.

SARMENTO, Daniel; SOUZA NETO, Cláudio Pereira de. Direito constitucional: teoria, história e métodos de trabalho. Belo Horizonte: Fórum, 2012.

SARTORI, Giovanni. A teoria da democracia revistada. v. I. Tradução de Dinah de Abreu Azevedo. São Paulo: Ática, 1994.

SILVA, Cecília de Almeida et al. Diálogos institucionais e ativismo. Curitiba: Juruá, 2010.

TOCQUEVILLE, Alexis de. Die gesellschafltiche un politische Zustände Frankreiches vor und nach 1798. In:TOCQUEVILLE, Alexis de. Das Zeitalter der Gleichheit - Auswahl aus Werken und Briefen. Zweite neubearbeitete und erweitere Auflage. Hrsg. u. übersetzt v. Siegfried Landshut. Köln und Opladen: Westdeutscher Verl., 1967. p. 117-140.

TUSHNET, Mark. Taking the Constitution away from the courts. Princeton: Princeton University Press, 1999.

VIEIRA, António. Sermão da Terceira Dominga do Advento. V. I. Obras Completas do Padre António Vieira - Sermões. Porto: Lello \& Irmão Editores, 1993. 